ISSN: 2302-8556

E-Jurnal Akuntansi Universitas Udayana

Vol.26.2.Februari (2019): 1269-1298

DOI: https://doi.org/10.24843/EJA.2019.v26.i02.p16

\title{
Faktor-Faktor Yang Berpengaruh Pada Akuntabilitas Pengelolaan Dana
} Desa

\author{
Ni Komang Ayu Julia Praba Dewi ${ }^{1}$ \\ Gayatri $^{2}$ \\ ${ }^{1,2}$ Fakultas Ekonomi dan Bisnis Universitas Udayana (Unud), Bali, Indonesia \\ e-mail: prabadewi63@gmail.com
}

\begin{abstract}
ABSTRAK
Penelitian ini bertujuan memperoleh bukti empiris pengaruh kompetensi, kepemimpinan, dan partisipasi pada akuntabilitas pengelolaan dana desa. Akuntabilitas pengelolaan dana desa merupakan pertanggungjawaban pemerintah desa pada masyarakat terkait pengelolaan danadesa. Penelitian dilakukan di 14 desa se-Kecamatan Abang, Kabupaten Karangasem. Responden dalam penelitian ini sebanyak 140 orang yang ditentukan menggunakan metode non-probability sampling yaitu purposive sampling. Data dikumpulkan dengan metode kuesioner. Teknik analisis data menggunakan uji regresi linear berganda. Hasil penelitian menunjukkan kompetensi, kepemimpinan, dan partisipasi berpengaruh positif pada akuntabilitas pengelolaan dana desa.
\end{abstract}

Kata Kunci: Akuntabilitas, kompetensi, kepemimpinan, partisipasi.

\begin{abstract}
This study aims to obtain empirical evidence of the influence of competence, leadership, and participation in accountability of village fund management. This study was conducted on 14 village in Abang District, Karangasem Regency. Respondents in this study were 140 people who were determined using a non-probability sampling, namely purposive sampling. Data collected by questionnaire method. Data analysis technique used in this study is multiple linear regression test. The result of the study showed that competency, leadership, and participation had a positive effect on the accountability of village fund management.
\end{abstract}

Keywords: Accountabilitty, competence, leadership, participation.

\section{PENDAHULUAN}

Undang-Undang (UU) Nomor 6 Tahun 2014 tentang Desa merupakan salah satu implikasi dari agenda prioritas pembangunan nasional dalam pemerintahan Presiden Jokowi yang menyatakan bahwa pemerintah akan membangun Indonesia dari pinggiran dengan memperkuat daerah-daerah dan desa dalam kerangka negara kesatuan. Pemerintah desa diharapkan dapat mengelola wilayahnya secara mandiri termasuk di dalamnya pengelolaan aset, keuangan, dan pendapatan desa sehingga dapat meningkatkan kualitas hidup di desa dan kesejahteraan masyarakat 
Ni Komang Ayu Julia Praba Dewi dan Gayatri. Faktor...

(Firmanzah, 2014). Tuntutan mengenai akuntabilitas pengelolaan dana desa kini menjadi fokus penting bagi perangkat desa, sebab akuntabilitas menunjukkan keberhasilan tercapainya visi dari Undang-Undang Desa untuk mewujudkan desa yang maju, kuat, mandiri, berkeadilan dan demokratis, memiliki kewenangan penuh dalam mengurus/mengatur diri sendiri untuk mencapai kesejahteraan masyarakat desa. Akuntabilitas menunjukkan bahwa pejabat publik telah bertindak dengan benar, berperilaku etis, serta bertanggungjawab atas kinerjanya. Dengan kata lain, akuntabilitas menjadi tolak ukur komitmen yang dimiliki pejabat publik dalam hal ini pejabat desa, terhadap organisasi dan masyarakat yang dipimpinnya.

Pada tahun 2017 Kabupaten Karangasem menerima dana desa sebesar Rp 63.682.742.000 yang telah disalurkan ke 75 desa yang tersebar di delapan kecamatan (www.djpk.depkeu.go.id). Jumlah ini meningkat dari alokasi tahun 2016 sebesar Rp 49.301.984.000. Akan tetapi, pada tahun 2018 dana desa untuk Provinsi Bali mengalami penurunan. Pada tahun 2017 total dana desa yang diterima Bali adalah sebesar Rp 537,25 miliar, tahun 2018 turun menjadi sekitar Rp 531 miliar. Penurunan dana desa tersebut tidak berdampak pada Kabupaten Buleleng dan Kabupaten Karangasem yang justru mengalami kenaikan penerimaan dana desa.

Berkaitan dengan kebijakan dana desa, Badan Pemeriksa Keuangan menyebutkan adanya permasalahan dalam pengelolaan keuangan desa yang bersumber dari minimnya pengetahuan perangkat desa dalam tata kelola dan pelaporan keuangan sehingga berpotensi terjadi penyelewengan atau korupsi 
(Abidin, 2015). Indonesia Corruption Watch (ICW) menyebutkan ada empat faktor yang menyebabkan terjadinya korupsi dana desa, diantaranya; pertama, kurangnya partisipasi masyarakat dalam proses perencanaan serta pengawasan dana desa; kedua,masih kurangnya kompetensi yang dimiliki oleh kepala desa dan perangkat desa; ketiga, lembaga desa yang belum sepenuhnya diberdayakan, dan keempat, kompetitifnya arena pemilihan kepala desa yang mengakibatkan tingginya cost politik (www.antikorupsi.org). Penelitian oleh Aziz (2016) menyatakan beberapa hambatan dalam pengelolaan dana desa diantaranya adalah kurangnya kapasitas sumber daya manusia pemerintahan desa dan kurangnya tingkat partisipasi masyarakat. Selain itu Nurjaman (2015) menyatakan bahwa pembangunan desa dapat berhasil karena beberapa faktor, yakni kapasitas perangkat desa, partisipasi masyarakat, dan kepemimpinan kepala desa.

Sumber daya manusia (SDM) merupakan faktor penting dalam organisasi atau lembaga pemerintahan, sebab merekalah yang akan menjalankan operasional organisasi. Tingginya kompetensi SDM dalam suatu organisasi menentukan kualitas dari organisasi tersebut. Penelitian Thomas (2013) menyatakan kurangnya kompetensi dari sumber daya manusia perangkat desa merupakan salah satu penghambat dalam pengelolaan dana desa. Sejalan dengan hal tersebut Santoso (2016) menyatakan kompetensi sumber daya manusia berpengaruh signifikan terhadap akuntabilitas keuangan daerah.

Kepemimpinan menjadi salah satu indikator kompetensi yang dimiliki kepala desa. Kesuksesan atau kegagalan suatu organisasi ditentukan oleh banyak hal, yang salah satunya adalah kepemimpinan yang berjalan dalam organisasi 
Ni Komang Ayu Julia Praba Dewi dan Gayatri. Faktor...

tersebut (Fathoni dkk., 2015). Semakin baik tokoh pemerintah mengetahui kepentingan masyarakat dan memiliki hubungan kerja sama yang baik dengan masyarakat, maka masyarakat akan semakin baik dalam melaksanakan dan membantu pemerintah dalam pengelolaan program pembangunan tersebut. Penelitian oleh Wahyuni (2015) menyatakan bahwa gaya kepemimpinan berpengaruh positif terhadap kinerja pegawai.

Tiga alasan partisipasi masyarakat mempunyai sifat sangat penting menurut Mahayani (2017), yakni; pertama, partisipasi masyarakat merupakan alat untuk memperoleh informasi mengenai kondisi, kebutuhan, dan sikap masyarakat setempat;kedua, masyarakat akan lebih mempercayai program kegiatan pembangunan apabila mereka dilibatkan dalam persiapan dan perencanaannya dan ketiga, mendorong partisipasi umum. Penelitian oleh Naimah (2017), memperoleh hasil bahwa partisipasi masyarakat berpengaruh signifikan terhadap akuntabilitas keuangan desa. Partisipasi masyarakat bukan hanya melibatkan masyarakat dalam pembuatan keputusan di setiap program pembangunan, namun masyarakat juga dilibatkan dalam mengidentifikasi masalah dan potensi yang ada di masyarakat (Tumbel, 2017). Pengelolaan dana desa membutuhkan partisipasi masyarakat, sebab prioritas penggunaan dana desa salah satunya adalah pemberdayaan masyarakat. Dalam usaha memberdayakan masyarakat di berbagai kegiatan atau aktivitas desa, maka partisipasi merupakan hal wajib yang harus dilakukan. Pemberdayaan masyarakat hanya mampu tercapai apabila masyarakat turut berpartisipasi aktif dalam kegiatan desa, seperti turut serta dalam pembangunan jalan desa. 
Kabupaten Karangasem menjadi sampel pemeriksaan oleh BPK RI pada tahun anggaran 2015 dan 2016 terkait pengelolaan dana desa. Selain itu penurunan penerimaan dana desa Provinsi Bali tahun anggaran 2018 tidak berdampak pada Kabupaten Karangasem. Kecamatan Abang sebagai salah satu kecamatan di Kabupaten Karangasem memiliki jumlah desa terbanyak yaitu 14 desa, dan memperoleh penerimaan dana desa terbesar selama 4 tahun terakhir terhitung sejak tahun 2015.

Fenomena tersebut melatarbelakangi peneliti untuk melakukan penelitian mengenai pengaruh kompetensi perangkat desa, kepemimpinan kepala desa, dan partisipasi masyarakat pada akuntabilitas pengelolaan dana desa di Kecamatan Abang, Kabupaten Karangasem. Penelitian ini bertujuan untuk memperoleh bukti empiris mengenai pengaruh kompetensi, kepemimpinan, dan partisipasi pada akuntabilitas pengelolaan dana desa. Secara teoritis penelitian ini berguna untuk mengkonfirmasi teori agensi mengenai perbedaan kepentingan antara prinsipal dan agen yang dapat diminimalisir melalui kompetensi yang memadai perangkat desa, kepemimpinan dari kepala desa, dan partisipasi aktif masyarakat. Secara praktis penelitian ini berguna sebagai bahan masukan bagi jajaran pemerintah desa se-Kecamatan Abang dalam upaya mewujudkan akuntabilitas pengelolaan dana desa.

Teori agensi menjelaskan mengenai hubungan antara pemilik perusahaan yang memberi wewenang kepada manajemen untuk mengelola sumber daya dalam menjalankan perusahaan. Teori agensi berfokus pada biaya potensi konflik kepentingan antara pelaku dan agen, disebut sebagai agency costs (Pepper dan 
Ni Komang Ayu Julia Praba Dewi dan Gayatri. Faktor...

Gore, 2014). Teori agensi berfokus pada masalah yang timbul di perusahaan sebagai akibat dari adanya pemisahaan kekuasaan antara prinsipal dengan agen, dan menekankan pada solusi dari masalah tersebut. Teori ini membantu dalam melaksanakan mekanisme corporate governance sebagai wujud kontrol pihak prinsipal terhadap agen di perusahaan (Panda dan Leepsa, 2017). Teori agensi juga termasuk masalah keagenan yang terjadi ketika ada tujuan dan pembagian kerja yang berbeda antara pihak-pihak yang bekerja sama (Homayoun, 2015). Dengan demikian, teori agensi memberikan alasan yang kuat mengapa mempertahankan mekanisme kontrol diperlukan (Namazi, 2013).

Pemisahan antara kepemilikan dengan pengawasan menyebabkan manajer sering bertindak menyimpang dari kepentingan pemilik. Situasi semacam ini menimbulkan masalah keagenan, yaitu manajer mungkin tidak bertindak demi kepentingan terbaik pemilik karena perbedaan motivasi. Prinsipal, berjuang untuk mengontrol dan memantau aktivitas para agen (Yusof, 2016). Pemisahan kepemilikan ini menyebabkan situasi dimana pemegang saham gagal untuk mengamati perilaku manajer. Ini dapat mengarah pada pertumbuhan risiko bahwa manajer tidak akan bertindak demi kepentingan pemegang saham dan dapat mulai berperilaku oportunistik (Boučková, 2015). Implikasi teori agensi dalam akuntabilitas pengelolaan dana desa adalah perangkat desa sebagai pihak yang diberikan wewenang (agen) oleh pemerintah pusat dan daerah (prinsipal) untuk mengelola dana desa. Selain itu, masyarakat dalam hal ini juga merupakan prinsipal, sehingga pemerintah desa harus mempertanggungjawabkan pengelolaan dana desa tidak hanya kepada pemerintah pusat dan daerah, tetapi juga kepada 
masyarakat. Konsekuensi dari teori agensi adalah tuntutan akuntabilitas dalam pengelolaan dana desa. Dalam mewujudkan akuntabilitas tersebut dibutuhkan kompetensi yang memadai dari perangkat desa, dorongan dan motivasi dari pemimpin yang tercermin dari kepemimpinan kepala desa, dan partisipasi aktif masyarakat sebagai wujud mekanisme kontrol prinsipal.

Teori peran adalah perspektif dalam sosiologi dan psikologi sosial yang menganggap sebagian besar aktivitas sehari-hari menjadi akting dari kategori yang didefinisikan secara sosial (misalnya; ibu, pengelola, guru). Setiap peran sosial adalah satu sethak, tugas, harapan, norma dan perilaku yang harus dihadapi dan dipenuhi seseorang (Şeşen, 2015). Pemegang status dalam penelitian ini adalah kepala desa yang berperan sebagai pemimpin, perangkat desa dengan perannya dalam melaksanakan operasional desa, ketua Lembaga Pemberdayaan Masyarakat, ketua Badan Permusyawaratan Desa, ketua PKK sebagai kelembagaan desa yang mendukung pemerintah desa dalam mewujudkan kesejahteraan masyarakat desa, dan masyarakat dalam perannya sebagai partisipan dalam proses pengambilan keputusan.

Teori kepatuhan menggambarkan kecenderungan seseorang untuk patuh pada norma dan peraturan yang ada. Kepatuhan menunjukkan apakah pihak-pihak yang terlibat telah melaksanakan tugasnya sesuai dengan standar yang telah ditetapkan. Seorang individu cenderung mematuhi hukum yang mereka anggap sesuai dan konsisten dengan norma-norma internal mereka (Ganesha, 2015). Teori kepatuhan diterapkan pada pemerintahan desa dalam menjalankan UndangUndang desa mulai dari perencanaan hingga pada tahap pengelolaan, harus sesuai 
Ni Komang Ayu Julia Praba Dewi dan Gayatri. Faktor...

pada aturan yang telah ditetapkan, sehingga pemerintah desa dapat mewujudkan tata kelola pemerintahan yang baik (Rabb dan Muchlis, 2016). Kepatuhan terhadap pelaporan keuangan dana desa mencerminkan kompetensi perangkat desa dalam memahami peraturan perundang-undangan yang berlaku. Kepatuhan bertujuan untuk mendapatkan lebih banyak pemahaman bagaimana organisasi harus beroperasi dalamcara yang lebih berkelanjutan untuk terus memberikan layanan mereka sambil mengamati semuanya secara ketat sesuai peraturan yang dapat mempengaruhi operasi bisnis mereka secara signifikan (Olivieri, 2014).

Tingkat kompetensi karyawan berdampak pada kinerja karyawan, maka masuk akal untuk menginvestasikan waktu dan sumber daya keuangan perusahaan untuk meningkatkan kompetensi karyawan (Kolibáčová, 2014). Kompetensi aparatur desa mutlak diperlukan agar pengelolaan dana desa untuk pengembangan berbagai aspek dapat dicapai dengan menggunakan kecerdasan, pengetahuan dan keterampilan serta perilaku untuk mendorong pembangunan desa yang optimal (Anto dan Amir, 2017). Sebagai syarat untuk dianggap mampu oleh masyarakat dalam melaksanakan tugas di bidang pekerjaan tertentu maka ia harus memiliki pengetahuan, keterampilan dan keahlian yang berkaitan dengan pekerjaannya.

Kepemimpinan adalah proses mempengaruhi orang lain untuk memahami dan setuju tentang apa yang perlu dilakukan dan bagaimana melakukannya, dan proses memfasilitasi upaya individu secara kolektif untuk mencapai tujuan bersama (Yukl, 2016). Kepemimpinan dianggap sebagai bentuk kontrol terpusat dimana satu individu memberikan kekuasaan dan mempengaruhi orang lain. Kepemimpinan merupakan kemampuan untuk mempengaruhi suatu kelompok 
menuju pencapaian sebuah visi atau tujuan yang ditetapkan (Robbins dan Judge, 2015). Pengetahuan dan keterampilan berkontribusi langsung pada proses kepemimpinan, sementara atribut lainnya memberi pemimpin karakteristik tertentu yang menjadikan pemimpin tersebut unik dibandingkan yang lainnya (Sharma dan Jain, 2013). Berbagai aktivitas yang ada dalam suatu lembaga atau organisasi tidak akan lepas dari arahan dan kontrol dari pimpinan karena pemimpin akan bertanggungjawab terhadap pendelegasian sebagian wewenangnya kepada subordinatnya.

Masyarakat sebagai lingkungan terdekat pemerintah desa merupakan subjek strategis untuk menjalankan fungsi pengawasan pengelolaan dana desa. Partisipasi publik adalah salah satu andalan utama demokrasi, dan secara tak terelakkan mempengaruhi tujuan kebijakan publik (Carreira dan Vasconcelos, 2016). Partisipasi mengacu pada keterlibatan langsung publik dalam pengambilan keputusan proses melalui berbagai mekanisme formal dan informal (Kulözü, 2016). Partisipasi masyarakat sangat dibutuhkan mengingat sensitivitas pengelolaan dana desa yang rentan terhadap penyelewengan. Keberhasilan penyelenggaraan pengelolaan dana desa tidak terlepas dari partisipasi aktif masyarakat desa sebagai bagian integral dari sistem pemerintahan.

Akuntabilitas sangat dibutuhkan sebagai bentuk pertanggungjawaban pemerintah desa kepada masyarakat. Akuntabilitas sendiri menjadi sangat sensitif karena menyangkut kewajiban pemerintah desa untuk mempertanggungjawabkan anggaran yang ada. Masyarakat tidak hanya diberikan informasi mengenai adanya anggaran desa, tetapi juga harus diberikan laporan pertanggungjawaban terkait 
Ni Komang Ayu Julia Praba Dewi dan Gayatri. Faktor...

realisasi dari anggaran tersebut. Dalam kaitannya dengan pertanggungjawaban, Wiguna dkk., (2015) menyatakan akuntabilitas pemerintah tidak dapat diketahui tanpa pemerintah memberitahukan kepada rakyat tentang informasi sehubungan dengan pengumpulan sumber daya dan sumber dana masyarakat serta penggunaannya.

Desa menjadi kesatuan masyarakat hukum yang memiliki kewenangan untuk mengatur dan mengurus kepentingan masyarakat setempat berdasarkan asal usul dan adat istiadat setempat yang diakui dalam sistem pemerintahan nasional dan berada di daerah kabupaten (Gayatri dkk., 2017). Pemberian bantuan langsung berupa dana desa menjadi wujud nyata kebijakan pemerintah dalam upaya mengembangkan desa dengan mendukung perbaikan infrastruktur fisik maupun non fisik desa(Oleh, 2014). Program dana desa bertujuan untuk mewujudkan pertumbuhan ekonomi dan pemerataan pendapatan dengan prioritas untuk membiayai pengembangan dan pemberdayaan masyarakat, misalnya program dan kegiatan terutama di bidang kegiatan Badan Usaha Milik Desa (BUMDesa), fasilitas penyimpanan air untuk irigasi desa, produk unggulan desa, dan fasilitas olah raga desa (Yunita dan Christianingrum, 2018). Dana desa merupakan salah satu upaya pemerintah mewujudkan pemerataan dalam berbagai bidang kehidupan yang dimulai dari level paling bawah.

Jensen dan Meckling (1976) menyatakan hubungan keagenan di dalam teori agensi (agency theory) bahwa perusahaan merupakan kumpulan kontrak (nexus of contract) antara pemilik sumber daya ekonomis (prinsipal) dan manajer (agen) yang mengurus penggunaan dan pengendalian sumber daya tersebut.Pemilik 
menginginkan kejelasan terkait modal yang diberikan kepada manajer dalam pelaksanaannya. Adanya teori keagenan diharapkan dapat mengurangi konflik yang dapat menyebabkan kesenjangan antara pemerintah dan masyarakat, dengan cara masyarakat sebagai prinsipal melakukan pengawasan atas apa yang dilakukan oleh agen. Akuntabilitas harus diimbangi dengan kemampuan perangkat desa dalam mengelola anggaran. Perangkat desa dengan kompetensi yang memadai tentunya akan mendukung dalam keberhasilan pengelolaan dana desa. Pemerintah desa sebagai agen harus mampu patuh terhadap aturan terkait pengelolaan dana desa, terlebih jumlah dana desa yang diterima desa selalu meningkat setiap tahun dan diawasi secara ketat oleh pemerintah pusat. Pengelolaan dana desa masih memiliki banyak kendala dalam pelaksananya, salah satunya dari faktor sumber daya manusia (SDM). Kompetensi berpengaruh positif pada pengelolaan laporan keuangan dana desa (Indrajaya, 2017). Pernyataan tersebut sejalan dengan hasil penelitian Mahayani (2017) yakni kompetensi sumber daya manusia berpengaruh positif pada akuntabilitas pengelolaan dana desa dalam konteks budaya Tri Hita Karana. Berdasarkan uraian tersebut, maka hipotesis yang dikembangkan dalam penelitian ini sebagai berikut.

$\mathrm{H}_{1} \quad$ : Kompetensi perangkat desa berpengaruh positif pada akuntabilitas pengelolaan keuangandana desa.

Teori agensi membutuhkan kekuasaan institusi/organisasi sebagai dasar untuk mempengaruhi dalam hubungan prinsipal dengan agen. Kekuasaan untuk mempengaruhi tersebut tidak lain berasal dari pemimpin, dalam hal ini adalah kepala desa. Kepemimpinan adalah suatu proses pengaruh interaktif yang terjadi ketika, dalam konteks tertentu, beberapa orang menerima seseorang sebagai milik 
Ni Komang Ayu Julia Praba Dewi dan Gayatri. Faktor...

mereka untuk mencapai tujuan bersama (Silva, 2016). Aktivitas yang dilakukan dalam suatu lembaga atau organisasi tidak akan terlepas dari peran pemimpin karena pemimpin bertanggungjawab terhadap seluruh kegiatan operasional organisasi. Kepala desa merupakan pemimpin formal tertinggi dalam pemerintahan desa. Kepala desa sebagai kepala pemerintahan desa adalah pemegang kekuasaan pengelolaan keuangan desa dan mewakili pemerintah desa dalam kepemilikan kekayaan desa (Bastian, 2015). Kepemimpian kepala desa berpengaruh dalam memotivasi dan mendorong kinerja karyawan dalam menjalankan tugas pemerintahan desa tak terkecuali dalam pengelolaan dana desa.

Penelitian oleh Aimbu dkk., (2016) menyatakan bahwa kepemimpinan transformasional berpengaruh positif pada akuntabilitas pengelolaan keuangan daerah.Penelitian oleh Dharmanegara et al., (2013) menunjukkan bahwa kepemimpinan transformasional berpengaruh signifikan pada akuntabilitas kinerja. Sejalan dengan itu, penelitian Ratu (2017) menunjukkan hasil bahwa gaya kepemimpinan berpengaruh positif pada kinerja penyusun laporan akuntabilitas kinerja instansi pemerintah.

Berdasarkan hal tersebut maka hipotesis yang dikembangkan dalam penelitian ini sebagai berikut.

$\mathrm{H}_{2}$ : Kepemimpinan kepala desa berpengaruh positif pada akuntabilitas pengelolaan keuangandana desa.

Dalam hubungan keagenan, masyarakat merupakan prinsipal, sehingga merupakan hak masyarakat untuk memperoleh pertanggungjawaban atas pengelolaan dana desa oleh agen, yakni pemerintah desa. Partisipasi masyarakat dapat membantu berbagai kegiatan desa, tak terkecuali pembangunan desa. 
Partisipasi masyarakat dapat diartikan sebagai keikutsertaan masyarakat dalam segala proses penetapan kebijakan maupun anggaran pemerintah sebagai wujud pengendalian terhadap pihak manajemen dalam menjalankan organisasi.

Partisipasi masyarakat meningkatkan pembangunan desa (Sugista, 2017). Penelitian yang dilakukan oleh Mada dkk., (2017) menunjukkan bahwa partisipasi masyarakat berpengaruh positif dan signifikan terhadap akuntabilitas pengelolaan dana desa.

Berdasarkan uraian di atas, hipotesis yang dikembangkan adalah.

$\mathrm{H}_{3}$ : Partisipasi masyarakat berpengaruh positif pada akuntabilitas pengelolaan keuangandana desa.

\section{METODE PENELITIAN}

Penelitian ini dilakukan dengan menggunakan pendekatan kuantitatif yang berbentuk penelitian asosiatif. Penelitian dilakukan di pemerintahan desa Kecamatan Abang, Kabupaten Karangasem. Variabel dependen dalam penelitian ini adalah akuntabilitas pengelolaan dana desa (Y), sedangkan variabel independennya antara lain kompetensi perangkat desa (X1), kepemimpinan kepala desa (X2), dan partisipasi masyarakat (X3). Populasi dalam penelitian ini adalah perangkat desa di seluruh Desa se-Kecamatan Abang, dan sampel yang digunakan sebanyak 180 orang yang ditentukan menggunakan metode non-probability sampling yaitu teknik purposive sampling, dengan kriteria yakni merupakan perangkat desa yang terdiri atas; sekretaris desa, kepala urusan keuangan, kepala urusan perencanaan, dan kepala dusun; kelembagaan desa diantaranya; ketua 
Ni Komang Ayu Julia Praba Dewi dan Gayatri. Faktor...

LPM, ketua BPD, dan ketua PKK; serta memiliki masa kerja minimal 1 tahun. Berikut merupakan rancangan desain penelitian.

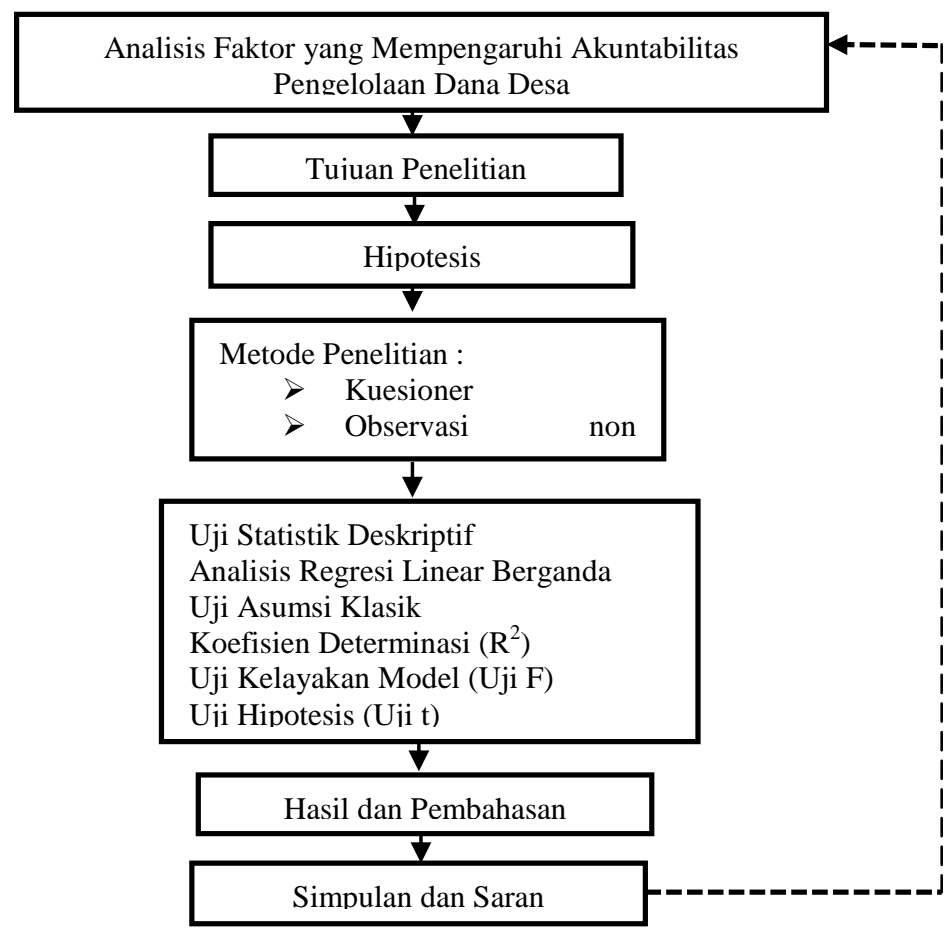

\section{Gambar 1. Desain Penelitian}

Sumber : Data diolah, 2018

Metode pengumpulan data menggunakan kuesioner dengan dengan skala

Likert modifikasi yang terdiri atas 4 pilihan jawaban, yaitu poin 4 Sangat Setuju (SS), poin 3 Setuju (S), poin 2 Tidak Setuju (TS), dan poin 1 Sangat Tidak Setuju (STS). Teknik analisis data yang digunakan dalam penelitian ini adalah analisis regresi linear berganda, dengan tahapan (1) uji statistik deskriptif, (2) uji asumsi klasik, (3) analisis regresi linear berganda, (4) pengujian hipotesis meliputi uji koefisien determinasi $\left(\mathrm{R}^{2}\right.$ ), uji kelayakan model (uji F), dan uji hipotesis (uji t). Analisis regresi linear berganda dilakukan untuk mengetahui pengaruh kompetensi perangkat desa, kepemimpinan kepala desa, dan partisipasi 
masyarakat terhadap akuntabilitas pengelolaan dana desa. Model regresi berganda dirumuskan dalam bentuk sebagai berikut.

$$
\mathrm{Y}=\alpha+\beta_{1} \mathrm{X}_{1}+\beta_{2} \mathrm{X}_{2}+\beta_{3} \mathrm{X}_{3}+\mathrm{e}+\ldots
$$

Keterangan:

$\mathrm{Y}=$ Akuntabilitas Pengelolaan Dana Desa

$\alpha \quad=$ Konstanta

$\beta_{1} \cdot \beta_{2} \cdot \beta_{3}=$ Koefisien Regresi Variabel X1, X2, dan X3

$\mathrm{X}_{1} \quad=$ Kompetensi Perangkat Desa

$\mathrm{X}_{2} \quad=$ Kepemimpinan Kepala Desa

$\mathrm{X}_{3} \quad=$ Partisipasi Masyarakat

$\mathrm{e} \quad=$ Eror

\section{HASIL DAN PEMBAHASAN}

Responden dalam penelitian ini adalah penyelenggara pemerintahan desa di Kecamatan Abang, Kabupaten Karangasem, diantaranya sekretaris desa, kaur keuangan, kaur perencanaan, seluruh kepala wilayah/kepala dusun, ketua LPM, ketua BPD, dan ketua PKK. Ringkasan pengiriman serta pengembalian kuesioner disajikan dalam tabel 1 . berikut.

Tabel 1.

Ringkasan Pengiriman dan Pengembalian Kuesioner

\begin{tabular}{|c|c|c|}
\hline Kuesioner & Jumlah & Persentase (\%) \\
\hline Kuesioner dikirim & 180 & 100 \\
\hline Kuesioner kembali & 156 & 86,67 \\
\hline Kuesioner tidak kembali & 24 & 13,33 \\
\hline Kuesioner yang gugur & 16 & 10,27 \\
\hline Kuesioner yang digunakan & 140 & 89,74 \\
\hline
\end{tabular}

Sumber : Data diolah, 2018

Berdasarkan tabel 1. dapat diketahui bahwa terdapat 16 kuesioner yang gugur atau tidak digunakan karena tidak memenuhi syarat yakni masa jabatan minimal 1 tahun, sehingga banyak kusioner yang digunakan adalah sebanyak 140 kuesioner. 
Ni Komang Ayu Julia Praba Dewi dan Gayatri. Faktor...

Validitas menurut Sugiyono (2017:125) menunjukan derajat ketepatan antara data yang sesungguhnya terjadi pada objek dengan data yang dikumpulkan oleh peneliti. Suatu instrumen dikatakan valid apabila nilai $\mathrm{r}$ pearson correlation terhadap skor total di atas 0,30. Hasil uji validitas disajikan pada Tabel 2.

Tabel 2. Hasil Uji Validitas

\begin{tabular}{|c|c|c|c|c|}
\hline No. & Variabel & Item & $\begin{array}{c}\text { Pearson } \\
\text { Correlation }\end{array}$ & Keterangan \\
\hline \multirow[t]{10}{*}{1} & Kompetensi (X1) & $\mathrm{X}_{1} .1$ & 0,454 & Valid \\
\hline & & $\mathrm{X}_{1} \cdot 2$ & 0,527 & Valid \\
\hline & & $\mathrm{X}_{1} \cdot 3$ & 0,536 & Valid \\
\hline & & $\mathrm{X}_{1} .4$ & 0,652 & Valid \\
\hline & & $X_{1} .5$ & 0,597 & Valid \\
\hline & & $X_{1} \cdot 6$ & 0,660 & Valid \\
\hline & & $X_{1} .7$ & 0,627 & Valid \\
\hline & & $\mathrm{X}_{1} .8$ & 0,697 & Valid \\
\hline & & $\mathrm{X}_{1} .9$ & 0,702 & Valid \\
\hline & & $X_{1} .10$ & 0,603 & Valid \\
\hline \multirow[t]{9}{*}{2} & Kepemimpinan (X2) & $\mathrm{X}_{2} .1$ & 0,525 & Valid \\
\hline & & $\mathrm{X}_{2} .2$ & 0,657 & Valid \\
\hline & & $\mathrm{X}_{2} .3$ & 0,655 & Valid \\
\hline & & $\mathrm{X}_{2} .4$ & 0,599 & Valid \\
\hline & & $X_{2} .5$ & 0,694 & Valid \\
\hline & & $X_{2} .6$ & 0,723 & Valid \\
\hline & & $X_{2} .7$ & 0,772 & Valid \\
\hline & & $\mathrm{X}_{2} .8$ & 0,659 & Valid \\
\hline & & $\mathrm{X}_{2} .9$ & 0,731 & Valid \\
\hline \multirow[t]{6}{*}{3} & Partisipasi (X3) & $\mathrm{X}_{3} .1$ & 0,745 & Valid \\
\hline & & $\mathrm{X}_{3} .2$ & 0,730 & Valid \\
\hline & & $\mathrm{X}_{3} .3$ & 0,770 & Valid \\
\hline & & $X_{3} .4$ & 0,763 & Valid \\
\hline & & $X_{3} .5$ & 0,597 & Valid \\
\hline & & $X_{3} .6$ & 0,656 & Valid \\
\hline \multirow[t]{8}{*}{4} & Akuntabilitas (Y) & Y.1 & 0,670 & Valid \\
\hline & & Y.2 & 0,699 & Valid \\
\hline & & Y.3 & 0,766 & Valid \\
\hline & & Y.4 & 0,756 & Valid \\
\hline & & Y.5 & 0,637 & Valid \\
\hline & & Y.6 & 0,716 & Valid \\
\hline & & Y.7 & 0,621 & Valid \\
\hline & & Y.8 & 0,642 & Valid \\
\hline
\end{tabular}

Sumber: Data diolah, 2018

Instrumen yang reliabel adalah instrumen yang bila digunakan beberapa kali untuk mengukur suatu objek yang sama, akan menghasilkan data yang sama (Sugiyono, 2014:173). Suatu instrumen dikatakan reliabel apabila nilai 
cronbach's alpha lebih dari 0,70 (Ghozali, 2013:47). Hasil uji reliabilitas disajikan dalam tabel 3 berikut.

Tabel 3.

Hasil Uji Reliabilitas

\begin{tabular}{lcc}
\hline \multicolumn{1}{c}{ Variabel } & Koefisien Alpha Cronbach & Keterangan \\
\hline Kompetensi (X1) & 0,807 & Reliabel \\
Kepemimpinan (X2) & 0,843 & Reliabel \\
Partisipasi (X3) & 0,805 & Reliabel \\
Akuntabilitas Pengelolaan Dana Desa (Y) & 0,838 & Reliabel \\
\hline
\end{tabular}

Sumber : Data diolah, 2018

Hasil uji reliabilitas pada Tabel 3 menunjukkan bahwa seluruh variabel memiliki nilai Alpha Cronbach lebih dari 0,70, sehingga dapat disimpulkan bahwa semua variabel dalam penelitian ini reliabel.

Statistik deskriptif bertujuan untuk mendeskripsikan data menjadi sebuah informasi yang mudah dipahami. Hasil analisis statistik deskriptif variabel Kompetensi, Kepemimpinan, dan Partisipasi terhadap Akuntabilitas Pengelolaan Dana Desa tersaji pada tabel 4 berikut.

Tabel 4.

Hasil Analisis Statistik Deskriptif

\begin{tabular}{lccccc}
\hline \multicolumn{1}{c}{ Variabel } & N & Minimum & Maksimum & Rata-rata & $\begin{array}{c}\text { Standar } \\
\text { Deviasi }\end{array}$ \\
\hline Kompetensi & 140 & 30,00 & 40,00 & 34,8429 & 3,07056 \\
Kepemimpinan & 140 & 26,00 & 36,00 & 30,4000 & 3,08582 \\
Partisipasi & 140 & 12,00 & 24,00 & 20,0786 & 2,36299 \\
Akuntabilitas & 140 & 20,00 & 32,00 & 27,0786 & 2,81330 \\
\hline Sumber $:$ Data diolah, 2018 & & &
\end{tabular}

Berdasarkan Tabel 4 diketahui deskripsi umum hasil penelitian sebagai berikut. Variabel Kompetensi memiliki nilai minimum sebesar 30,00 dan nilai maksimum sebesar 40,00. Nilai rata-rata sebesar 34,8429 dengan penyimpangan nilai rata-ratanya yang ditunjukkan melalui standar deviasi sebesar 3,07056. Variabel Kepemimpinan memiliki nilai maksimum sebesar 26,00 dan nilai maksimum sebesar 36,00. Nilai rata-rata sebesar 30,4000 dengan penyimpangan 
Ni Komang Ayu Julia Praba Dewi dan Gayatri. Faktor...

nilai rata-ratanya yang ditunjukkan melalui standar deviasi sebesar 3,08582. Variabel Partisipasi memiliki nilai maksimum sebesar 12,00 dan nilai maksimum sebesar 24,00. Nilai rata-rata sebesar 20,0786 dengan penyimpangan nilai rataratanya yang ditunjukkan melalui standar deviasi sebesar 2,36299. Variabel Akuntabilitas memiliki nilai maksimum sebesar 20,00 dan nilai maksimum sebesar 32,00. Nilai rata-rata sebesar 27,0786 dengan penyimpangan nilai rataratanya yang ditunjukkan melalui standar deviasi sebesar 2,81330.

Pengujian asumsi klasik bertujuan untuk memberikan kepastian bahwa persamaan regresi yang didapatkan memiliki ketepatan dalam estimasi, tidak bias dan konsisten.Uji normalitas bertujuan menguji apakah dalam model penelitian variabel terdistribusi secara normal atau tidak berdistribusi normal.Data dikatakan berdistribusi normal apabila koefisien Asymp. Sig. (2-tailed) lebih dari 0,05. Hasil pengujian normalitas disajikan dalam Tabel 5 berikut.

Tabel 5.

Hasil Uji Normalitas Data

\begin{tabular}{llr}
\hline & & Unstandardized Residual \\
\hline $\mathrm{N}$ & & 140 \\
Normal Parameters & Mean &, 0000000 \\
& Std. Deviation & 1,90411597 \\
Most Extreme Differences & Absolute &, 061 \\
& Positive &, 061 \\
& Negative &,- 042 \\
Test Statistic & &, 061 \\
Asymp. Sig. (2-tailed) & &, $200^{\mathrm{c}, \mathrm{d}}$ \\
Sumber $:$ Data diolah, 2018 & &
\end{tabular}

Hasil pengujian statistik menunjukkan bahwa nilai signifikansi Asymp. Sig. (2-tailed) sebesar 0,200 lebih dari 0,05. Hal ini menunjukkan bahwa model regresi berdistribusi normal.

Uji Multikoliniearitas bertujuan untuk menguji apakah pada model regresi ditemukan adanya korelasi antar variabel bebas. Adanya multikolinieritas dapat 
dilihat dari nilai tolerance atau Variance Inflation Factor (VIF). Apabila nilai tolerance lebih dari 0,01 atau VIF kurang dari 10, maka tidak ada multikolinieritas. Hasil pengujian multikolinieritas disajikan dalam Tabel 6.

Tabel 6.

Hasil Uji Multikolinieritas

\begin{tabular}{|c|c|c|c|}
\hline \multirow{2}{*}{ Model } & \multicolumn{2}{|c|}{ Collinearity Statistic } & \multirow{2}{*}{ Keterangan } \\
\hline & Tolerance & $V I F$ & \\
\hline Kompetensi & 0,681 & 1,468 & Tidak ada multikolinieritas \\
\hline Kepemimpinan & 0,596 & 1,677 & Tidak ada multikolinieritas \\
\hline Partisipasi & 0,721 & 1,388 & Tidak ada multikolinieritas \\
\hline
\end{tabular}

Sumber : Data diolah, 2018

Berdasarkan Tabel 6 dapat dilihat bahwa nilai tolerance masing-masing variabel lebih dari 0,1 dan nilai VIF kurang dari 10, sehingga dapat disimpulkan bahwa dalam model regresi tidak terjadi gejala multikolinieritas.

Uji Heteroskedastisitas bertujuan untuk menguji apakah dalam model regresi terjadi ketidaksamaan varians dari residual satu pengamatan ke pengamatan lain yang dilakukan dengan uji Glejser. Hasil uji heteroskedastisitas disajikan dalam tabel 7 berikut.

Tabel 7.

Hasil Uji Heteroskedastisitas

\begin{tabular}{lcc}
\hline \multicolumn{1}{c}{ Variabel } & Sig. & Keterangan \\
\hline Kompetensi $\left(\mathrm{X}_{1}\right)$ & 0,467 & Bebas Heteroskedastisitas \\
Kepemimpinan $\left(\mathrm{X}_{2}\right)$ & 0,302 & Bebas Heteroskedastisitas \\
Partisipasi $\left(\mathrm{X}_{3}\right)$ & 0,579 & Bebas Heteroskedastisitas \\
\hline
\end{tabular}

Sumber : Data diolah, 2018

Berdasarkan Tabel 7 diketahui bahwa nilai Sig. dari variabel Kompetensi, Kepemimpinan, dan Partisipasi lebih dari 0,05 yang berarti variabel-variabel tersebut tidak mengandung gejala heteroskedastisitas.

Analisis Regresi Linear Berganda diolah dengan bantuan software SPSS for Windows dengan hasil yang dapat dilihat pada Tabel 8 berikut. 
Tabel 8.

Hasil Uji Regresi Linear Berganda

\begin{tabular}{lccccc}
\hline \multirow{2}{*}{ Model } & \multicolumn{2}{c}{$\begin{array}{c}\text { Unstandardized } \\
\text { Coefficients }\end{array}$} & $\begin{array}{c}\text { Standardized } \\
\text { Coefficients }\end{array}$ & & \\
\cline { 2 - 4 } & $\boldsymbol{B}$ & Std. Error & Beta & $\boldsymbol{t}$ & Sig. \\
\hline (Constant) & 3,650 & 2,047 & & 1,783 &, 077 \\
Kompetensi (X1) & 0,131 & 0,064 & 0,143 & 2,032 &, 044 \\
Kepemimpinan (X2) & 0,260 & 0,069 & 0,286 & 3,800 &, 000 \\
Partisipasi (X3) & 0,545 & 0,081 & 0,458 & 6,700 &, 000 \\
Adjusted $R^{2}$ & 0,532 & & & & \\
F Hitung & 53,627 & & & & \\
Sig. F & 0,000 & & & & \\
Sumber $:$ Data diolah, 2018 & & & & &
\end{tabular}

Sehingga persamaan garis regresi linear berganda adalah sebagai berikut.

$Y=3,650+0,131 X_{1}+0,260 X_{2}+0,545 X_{3}+\varepsilon$

Berdasarkan model regresi tersebut, dapat diinterpretasikan sebagai berikut.

Nilai konstanta 3,650 menunjukkan apabila variabel Kompetensi ( $\left.\mathrm{X}_{1}\right)$, Kepemimpinan $\left(\mathrm{X}_{2}\right)$, dan Partisipasi $\left(\mathrm{X}_{3}\right)$ bernilai konstan, maka variabel Akuntabilitas Pengelolaan Dana Desa (Y) memiliki nilai positif sebesar 3,650. Variabel Kompetensi $\left(\mathrm{X}_{1}\right)$ memiliki nilai koefisien sebesar 0,131, menunjukkan bahwa ada pengaruh positif pada variabel Akuntabilitas (Y), yang artinya apabila variabel Kompetensi $\left(\mathrm{X}_{1}\right)$ naik sebesar satu satuan dengan asumsi variabel lain dianggap konstan, maka variabel Akuntabilitas (Y) meningkat sebesar 0,131.Variabel Kepemimpinan $\left(\mathrm{X}_{2}\right)$ memiliki nilai koefisien sebesar 0,260, menunjukkan bahwa ada pengaruh positif pada variabel Akuntabilitas (Y), yang artinya apabila variabel Kepemimpinan $\left(\mathrm{X}_{2}\right)$ naik sebesar satu satuan dengan asumsi variabel lain dianggap konstan, maka variabel Akuntabilitas (Y) meningkat sebesar 0,260. Variabel Partisipasi $\left(\mathrm{X}_{3}\right)$ memiliki nilai koefisien 
sebesar 0,545, menunjukkan bahwa ada pengaruh positif pada variabel Akuntabilitas $(\mathrm{Y})$, yang artinya apabila variabel Partisipasi $\left(\mathrm{X}_{3}\right)$ naik sebesar satu satuan dengan asumsi variabel lain dianggap konstan, maka variabel Akuntabilitas (Y) meningkat sebesar 0,545.

Koefisien determinasi menunjukkan seberapa besar pengaruh variabel bebas (X) pada variabel terikat (Y), yang ditunjukkan dengan nilai Adjusted $R$ Square. Nilai adjusted $R^{2}$ dalam penelitian ini yakni sebesar 0,532 menunjukkan bahwa 53,2\% variasi (naik-turunnya) variabel Akuntanbilitas (Y) dipengaruhi secara bersama-sama oleh variasi dari ketiga variabel bebas (kompetensi, kepemimpinan, dan partisipasi), sedangkan sisanya sebesar $46,8 \%$ dipengaruhi oleh variabel lain yang tidak dimasukkan dalam model penelitian. Hasil uji $\mathrm{F}$ menunjukkan bahwa nilai $\mathrm{F}$ hitung untuk variabel terikat akuntabilitas pengelolaan dana desa sebesar 53,627 dengan signifikansi sebesar 0,000. Nilai signifikansi $F=0,000$ kurang dari 0,05 menunjukkan signifikansi pengaruh variabel-variabel bebas terhadap variabel terikat adalah layak. Hal ini berarti bahwa variabel kompetensi, kepemimpinan, dan partisipasi mampu memprediksi atau menjelaskan fenomena akuntabilitas pengelolaan dana desa.

Uji t pada dasarnya bertujuan untuk menguji hipotesis apakah variabel independen berpengaruh signifikan pada variabel dependen (Ghozali, 2016:98). Hasil pengujian hipotesis pertama menunjukkan bahwa kompetensi bernilai positif pada akuntabilitas pengelolaan keuangan dana desa. Hasil uji t sebesar 2,032 dengan tingkat signifikansi sebesar 0,044 kurang dari tingkat signifikansi yang digunakan yaitu $\alpha=0,05$ sehingga $H_{1}$ diterima, yang berarti bahwa 
Ni Komang Ayu Julia Praba Dewi dan Gayatri. Faktor...

kompetensi perangkat desa berpengaruh positif pada akuntabilitas pengelolaan keuangan dana desa di Kecamatan Abang. Masalah keagenan dalam teori agensi terjadi karena adanya perbedaan kepentingan antara agen dan prinsipal. Hal tersebut dapat diminimalisir dengan cara meningkatkan kompetensi perangkat desa terkait pengelolaan dana desa, sehingga tuntutan akuntabilitas dapat tercapai. Kompetensi yang memadai dari perangkat desa dapat meningkatkan akuntabilitas, yang pada akhirnya dapat membantu prinsipal dalam menerapkan mekanisme kontrolnya. Teori kepatuhan menjelaskan terkait kemampuan seseorang untuk taat dan mengikuti apa yang sudah diatur atau yang sudah ditetapkan.Pemahaman perangkat desa terkait tata cara pengalokasian dan pertanggungjawaban dana desa mencerminkan kompetensi yang dimiliki individu dalam organisasi pemerintahan desa.

Penelitian oleh Mada dkk., (2017) memperoleh hasil bahwa kompetensi aparat pengelola dana desa berpengaruh positif dan signifikan terhadap akuntabilitas pengelolaan dana desa, yang berarti bahwa semakin kompeten aparat pengelola dana desa, maka pengelolaan dana desa semakin akuntabel. Dalam pengelolaan keuangan desa yang baik, aparatur pemerintah desa yang terkait harus memiliki sumber daya manusia yang kompeten, yang didukung dengan latar belakang pendidikan memadai, sering mengikuti pendidikan dan pelatihan, dan mempunyai pengalaman di bidang keuangan (Ferina, 2016). Kualitas sumber daya manusia berpengaruh positif terhadap kinerja pengelolaan keuangan (Azkia dkk., 2016). Penelitian-penelitian tersebut semakin memperkuat hasil penelitian ini 
terkait kompetensi perangkat desa berpengaruh positif pada akuntabilitas pengelolaan dana desa.

Hasil pengujian hipotesis kedua mengenai pengaruh kepemimpinan kepala desa pada akuntabilitas pengelolaan keuangan dana desa menunjukkan nilai signifikansi sebesar 0,000 kurang dari $\alpha=0,05$. Oleh karena itu hipotesis kedua dalam penelitian ini diterima, yang berarti bahwa variabel kepemimpinan berpengaruh positif pada akuntabilitas pengelolaan keuangan dana desa. Gaya kepemimpinan yang diterapkan kepala desa berpengaruh pada respon perangkat desa dalam melaksanakan tugasnya dalam mengelola keuangan desa. Teori agensi menjelaskan mengenai hubungan kontraktual antara prinsipal dan agen, dalam hal ini kepala desa bertanggung jawab sebagai pengambil keputusan terhadap perangkat desa sebagai agen yang ikut berperan dalam akuntabilitas pengelolaan dana desa. Teori peran menjelaskan mengenai interaksi antar individu yang menduduki peran tertentu dalam suatu organisasi. Kepala desa sebagai pemimpin dalam pemerintahan desa berperan dalam merencanakan, mengatur, mengorganisasikan, dan menentukan arah dan tujuan organisasi. Dengan demikian, diharapkan dapat meningkatkan motivasi kerja perangkat desa dan membawa pemerintahan desa mencapai akuntabilitas pengelolaan dana desa.

Kepemimpinan berpengaruh positif dan signifikan pada kinerja perusahaan yang menunjukkan bahwa semakin baik pelaksanaan kepemimpinan maka semakin baik kinerja perusahaan (Surya dkk., 2017). Penelitian oleh Hastuti (2017) menunjukkan bahwa gaya kepemimpinan berpengaruh signifikan terhadap akuntabilitas. Sejalan dengan penelitian Hardianti (2017) yang memperoleh hasil 
Ni Komang Ayu Julia Praba Dewi dan Gayatri. Faktor...

bahwa gaya kepemimpinan berpengaruh pada kinerja. Seorang pemimpin harus mampu memiliki cara agar mampu menggerakkan pegawai dan masyarakat dalam rangka pencapaian tujuan. Hal ini pula yang harus dimiliki oleh seorang kepala desa dalam melaksanakan kewenangannya (Ekaningtyas, 2016).

Hasil pengujian hipotesis kedua mengenai pengaruh partisipasi masyarakat pada akuntabilitas pengelolaan keuangandana desa menunjukkan nilai signifikansi sebesar 0,000 kurang dari $\alpha=0,05$. Oleh karena itu hipotesis ketiga dalam penelitian ini diterima, yang berarti bahwa variabel partisipasi berpengaruh positif pada akuntabilitas pengelolaan keuangan dana desa. Teori agensi menjelaskan mengenai perbedaan kepentingan yang dimiliki antara prinsipal dan agen, yang menyebabkan tidak ada jaminan bahwa agen akan selalu bertindak sesuai keinginan prinsipal. Dalam hal ini partisipasi masyarakat juga berperan penting dalam mengontrol aktivitas pemerintahan desa terkait pengelolaan dana desa. Masyarakat tidak hanya menerima pertanggungjawaban dari pemerintah desa, akan tetapi masyarakat juga dapat mengawasi langsung mulai dari tahap perencanaan, hingga tahap pengelolaannya.

Penelitian oleh Irma (2016), Arifiyanto dan Kurrohman (2014) menunjukkan bahwa akuntabilitas pengelolaan keuangan desa dapat terwujud dengan baik karena adanya partisipasi masyarakat. Sejalan dengan penelitian tersebut Apriliani (2016) dalam penelitiannya memperoleh hasil bahwa akuntabilitas pengelolaan alokasi dana desa sudah baik karena dalam tahap perencanaannya telah melibatkan masyarakat melalui musyawarah perencanaan pembangunan desa (musrenbangdes). Hasil tersebut memperkuat hasil penelitian 
ini yang menunjukkan bahwa partisipasi masyarakat berpengaruh pada akuntabilitas pengelolaan keuangan dana desa.

\section{SIMPULAN}

Kompetensi perangkat desa, kepemimpinan kepala desa, dan partisipasi masyarakat memiliki pengaruh positif pada akuntabilitas pengelolaan dana desa. Hal ini menunjukkan bahwa semakin tinggi kompetensi, kepemimpinan, dan partisipasi maka akuntabilitas pengelolaan dana desa akan semakin tinggi. Pemerintah desa se-Kecamatan Abang harus meningkatkan kompetensi yang dimiliki melalui pelatihan, bimbingan, penguasaan teknologi informasi, dan meningkatkan kerjasama antar perangkat desa. Selain itu pemerintah harus meningkatkan partisipasi masyarakat dalam berbagai aktivitas atau kegiatan desa. Kepala desa juga harus meningkatkan kapasitas dan kapabilitasnya dalam memimpin melalui komunikasi dan hubungan yang baik dengan bawahannya.

\section{REFERENSI}

Abidin, M. Z. (2015). Tinjauan atas pelaksanaan keuangan desa dalam mendukung kebijakan dana desa. Jurnal Ekonomi \& Kebijakan Publik, 6(1), 61-76.

Aimbu, L. L., Saerang, D. P. E., \& Gamaliel, H. (2017). (Studi empiris pada SKPD Pemerintah Kabupaten Kepulauan Talaud) Program Studi Magister Akuntansi Fakultas Ekonomi dan bisnis Universitas Sam Ratulangi Pendahuluan Kebijakan yang dibuat melalui perangkat aturan tentang keuangan daerah / negara, dapat di, 170-180.

Anto, R. P., \& Amir, M. (2017). Competence of Village Apparatus In Management of Village Funds in North Konawe Regency-Indonesia. IOSR Journal of Business and Management Ver. VII, 19(11), 2319-7668. 
Ni Komang Ayu Julia Praba Dewi dan Gayatri. Faktor...

Apriliani, Sherly Gresita. 2014. Akuntabilitas Pengelolaan Alokasi Dana Desa di Desa Kedyngrejo Kecamatan Muncar Kabupaten Banyuwangi Tahun 2013. Skripsi. Universitas Jember, Jember.

Arifiyanto, D. F., \& Kurrohman, T. (2014). Akuntabilitas Pengelolaan Dana Desa Di Kabupaten Jember. Jurnal Riset Akuntansi Dan Keuangan, 2(3), 473485.

Azkia, Basri.H, Darwanis. 2016. Pengaruh Kualitas Sumber Daya Manusia dan akuntbilitas Publik Terhadap Kinerja Pengelolaan Keuangan di Lingkungan Universitas Negeri Ar-Raniry Banda Aceh. Jurnal Telaah \& Riset Akuntansi, 22 (32): 2302-0164.

Bagus, I., Dharmanegara, A., \& Sudarma, M. (2013). Mediation Of Tri Hita Karana Organizational Culture In Effect Of Spiritual Intelligence And Asta Brata Leadership On Employee Performance. Interdisciplinary Journal Of Contemporary Research In Business, 11(2), 475-486.

Bastian, I. (2015). Akuntansi untuk Kecamatan dan Desa. Jakarta, Penerbit Erlangga.

Boučková, M. (2015). Management Accounting and Agency Theory. Procedia Economics and Finance, 25(15), 5-13. https://doi.org/10.1016/S22125671(15)00707-8

Carreira, V., Machado, J., \& Vasconcelos, L. (2016). Engaging Citizen Participation-A Result of Trusting Governmental Institutions and Politicians in the Portuguese Democracy. Social Sciences, 5(3), 40.

Direktorat Jenderal Perimbangan Keuangan. 2017. Transfer ke Daerah dan Dana Desa.http://www.djpk.depkeu.go.id. Diakses 20 September 2017.

Ekaningtyas, Nastuti. 2016. Pengaruh Gaya Kepemimpinan Terhadap Pemanfaatan Anggaran Pendapatan Dan Belanja Desa (Kasus Di Desa Cihideung Udik, Kecamatan Ciampea, Kabupaten Bogor). Skripsi. Sarjana Komunikasi dan Pengembangan Masyarakat pada Departemen Sains Komunikasi dan Pengembangan Masyarakat Institut Pertanian Bogor, Bogor.

Elif, Ş. (2015). Role Theory and Its Usefulness In Public Relations. European Journal of Business and Social Sciences, 4(01), 136-143.

Fathoni, M., \& Rengu, S. P. (2015). Dalam Pembangunan Fisik Desa ( Studi di Desa Denok Kecamatan Lumajang Kabupaten Lumajang ). Jurnal Administrasi Publik (JAP), 3(1), 139-146. 
Ferina, Ika Sasti. 2016. Tinjauan Kesiapan Pemerintah Desa dalam Implementasi Peraturan Menteri Dalam Negeri Nomor 113 tentang Pengelolaan Keuangan Desa (Studi Kasus pada Pemerintah Desa di Kabupaten Ogan Hir). Jurnal Manajemen dan Bisnis Sriwijaya, 14(3), hal.321-336.

Firmanzah. Pembangunan partisipatif melalui UU Desa. http://setkab.go.id/artikel-12385-.html. Diakses 22 Mei 2018.

Ganesha, A., \& Kiswara, E. (2015). Faktor-Faktor Yang Mempengaruhi Tingkat Kepatuhan Perusahaan Go Public Pada Konvergensi International Financial Reporting Standard (Studi Empiris pada Perusahaan yang Terdaftar di Index LQ45). Diponegoro Journal of Accounting.

Gayatri., Latrini, M Y. dan N L Sari Widhiyani. 2017. Transparansi dan Akuntabilitas Pengelolaan Keuangan Dana Desa untuk Mendorong Kemandirian Masyarakat Pedesaan. Jurnal Ekonomi Kuantitatif Terapan, 10(2), hal. 175-182.

Hardianti, Andi. 2016. Pengaruh Gaya Kepemimpinan Demokratis terhadap Kinerja Pegawai pada Kantor Dinas Pendapatan Daerah Kabupaten Wajo. Skripsi Sarjana Pendidikan Fakultas Ilmu Sosial pada Universitas Negeri Makassar, Makassar.

Hasniati. 2016. Model Akuntabilitas Pengelolaan Dana Desa. Jurnal Analisis Kebijakan dan Pelayanan Publik, 2(1), hal. 15-30.

Homayoun, Saed; Homayoun, S. (2015). Agency Theory and Corporate Governance. International Business Management.

Indrajaya, J. A. (2017). Pengaruh Kompetensi Aparatur Desa Dan Implementasi Undang-Undang No 6 Tahun 2014 Terhadap Pengelolaan Keuangan Dana Desa. Skripsi, (6), i-67.

Irma, A. (2015). Akuntabilitas Pengelolaan Alokasi Dana Desa (Add) Di Kecamatan Dolo Selatan Kabupaten Sigi. Katalogis, 3(1), 121-137.

Jensen, M C. and Meckling W H. 1976. The Theory of The Firm: Manajerial Behaviour, Agency Cost, and Ownership Structure. Journal Of Financial and Economics, 3(4), hal. 305-360.

Kolibácová, G. (2014). The relationship between competency and performance. Acta Universitatis Agriculturae et Silviculturae Mendelianae Brunensis, 62(6), 1315-1327. 
Ni Komang Ayu Julia Praba Dewi dan Gayatri. Faktor...

Kulözï*, N. (2015). Participation as a Means to an End or as an End in Itself: The Success Evaluations of Participants. Turkish Public Administration Annual, $41-42,83-102$.

Kumar Sharma, M., \& Shilpa Jain, M. (2013). Leadership Management: Principles, Models and Theories. Global Journal of Management and Business Studies, 3(3), 2248-9878.

Mada, S., Kalangi, L., \& Gamaliel, H. (2017). Pengaruh Kompetensi Aparat Pengelola Dana Desa , Komitmen Organisasi Pemerintah Desa, dan Partisipasi Masyarakat Terhadap Akuntabilitas Pengelolaan Dana Desa Di Kabupaten Gorontalo. Jurnal Riset Akuntansi Dan Auditing, Vol 8, No, 106115.

Mahayani, N. L. A. (2017). Prosocial Behavior Dan Persepsi Akuntabilitas Pengelolaan Dana Desa Dalam Konteks Budaya Tri Hita Karana. Jurnal Ilmiah Akuntansi Dan Bisnis, 12(2), 129-144.

Naimah. 2017. Faktor-Faktor Yang Mempengaruhi Akuntabilitas Keuangan Desa Pada Pemerintah Kabupaten Serdang Bedagai. Tesis Magister Jurusan Akuntansi pada Fakultas Ekonomi Dan Bisnis Universitas Sumatera Utara, Medan.

Namazi, M. (2013). Role of the agency theory in implementing managements control. Journal of Accounting and Taxation, 5(2), 38-47.

Nurjaman, R. 2015. Dinamika dan Problematika Implementasi UU Desa: Pembelajaran dari 2 Daerah di Jawa Barat. Jurnal Desentralisasi. 13(1).

Nyimas Latifah Letty Aziz. (2016). Otonomi Desa Dan Efektivitas Dana Desa. Jurnal Penelitian Politik, 13(2), 193-211.

Oleh, H. F. (2014). Pelaksanaan Kebijakan Alokasi Dana Desa ( ADD ) dalam Memberdayakan. Kebijakan Dan Manajemen Publik, 2(1), 1-8.

Olivieri,F. 2014. Compliance by Design. Synthesis of Business Processes by Declarative Specifications. Phd Dipartimentodi Informatica, Universitàdigli Studidi Verona, Italy and Institute for Integrated and Intelligent Systems, Griffith University, Australia.

Panda, B., \& Leepsa, N. M. (2017). Agency theory: Review of Theory and Evidence on Problems and Perspectives. Indian Journal of Corporate Governance, 10 (1), 74-95.

Pepper, A., \& Gore, J. (2015). Behavioral agency theory: new foundations for theorizing about executive compensation, (March). 
Rabb, A. D. A., \& Muchlis, M. (2016). 22 Akuntansi Peradaban: Vol. II No. 1 Juli 2016. Jurnal Ilmiah Akuntansi Peradaban, 2(1), 22-43.

Ratu, N.I. H. 2017. Kecerdasan Spiritual Memoderasi Gaya Kepemimpinan dan Budaya Organisasi pada Kinerja Penyusun Laporan Akuntabilitas Kinerja Instansi Pemerintah. Tesis Magister Jurusan Akuntansi pada Fakultas Ekonomi dan Bisnis Universitas Udayana, Bali.

Robbins, Stephen P. dan Timothy A. Judge. 2015. Perilaku Organisasi. Jakarta: Salemba Empat.

Santoso, E. B. (2016). Pengaruh Sistem Pengendalian Intern Pemerintah, Pemanfaatan Teknologi Informasi dan Kompetensi Sumber Daya ManusiaTerhadap Akuntabilitas Keuangan Daerah (Studi Empiris Pada Pemeritah Kabupaten Lampung Timur). Tesis, 16.

Silva, A. (2016). What is Leadership ? Journal of Business Studies Quarterly, $8(1), 1-5$.

Sjafrina, Almas., Primayogha Egi., Ramadhana, Kurnia. 2017. Cegah Meluasnya Korupsi Dana Desa!. https://www.antikorupsi.org/id/news/cegah-korupsidana-desa. Diakses 4 Juni 2018.

Sugista, R. A. (2017). Penagruh Transparansi, Akuntabilitas, dan Partisipasi dalam Pengelolaan Keuangan Desa terhadap Pembangunan Desa (StudiEmpiris di Kabupaten Lampung Selatan). Skripsi.

Sugiyono. 2017. Metode Penelitian Bisnis Kuantitatif, Kualitatit, dan R\&D. Bandung: PT. Alfabeta Cipta.

Thomas. 2013. Pengelolaan Alokasi Dana Desa dalam Upaya Meningkatkan Pembangunan di Desa Sebawang Kecamatan Sesayap Kabupaten Tana Tuding. Journal Pemerintahan Integratif, 1(1).

Tri, B., Karana, H., Organisasional, K., Studi, P., Fakultas, M., \& Udayana, U. (2017). Terhadap Kinerja Organisasi Ida Bagus Ketut Surya ; Anak Agung Sagung Kartika Dewi; I Wayan Mudiartha Utama; Anak Agung Ayu Sriathi ; Ni Wayan Mujiati, (19), 27-28.

Tumbel, S. M. (2017). Partisipasi Masyarakat Dalam Pengelolaan Dana Desa Di Desa Tumaluntung Satu Kecamatan Tareran Kabupaten Minahasa Selatan. Jurnal Politico, 6(1). 
Ni Komang Ayu Julia Praba Dewi dan Gayatri. Faktor...

Wahyuni, Evi. 2015. Pengaruh Budaya Organisasi dan Gaya Kepemimpinan Terhadap Kinerja Pegawai Bagian Keuangan Organisasi Sektor Publik dengan Motivasi Kerja Sebagai Variabel Intervening. Jurnal Nominal, 4(1), hal. 96-112.

Yukl G. 2016. Leadership in Organizations, 8th Edition.New York: Pearson.

Yunita, A., \& Christianingrum, M. (2018). Measurement of Accountability Management of Village Funds. Integrated Journal of Business and Economics, 2(1), 99-103.

Zalina, N., \& Yusof, M. (2016). Context Matters : A Critique of Agency Theory in Corporate Governance Research in Emerging Countries. International Journal of Economics and Financial Issues, 6(Special issue for International Soft Science conference), 154-158. 